\title{
Research on Scientific Inquiry Mode in the Application of Philosophy Teaching Base on Matrix Equation and Mathematical Statistics
}

\author{
Yali Wei \\ Department of Ideological Political, Xi'an Physical Education University, Xi'an, China \\ w_ei_yali@126.com
} Keywords:scientific inquiry teaching mode; marx doctrine; mathematical statistics; investigation
and analysis

\begin{abstract}
The scientific inquiry teaching mode is developing more slowly in our country, this paper first introduces the basic theory of scientific inquiry teaching method. Then it combines with Marx's education and teaching characteristics to establish Marx's teaching scientific inquiry teaching mode and operation of scientific inquiry teaching mode of specific procedures. In order to verify the scientific inquiry teaching modes, it can use mathematical statistics method; data show that, $74 \%$ of the students in the experiment group have a more profound understanding of the Marx doctrine by using inquiry mode teaching method. That is said inquiry teaching mode in Marx's education has the absolute advantage, and it can fully improve students' autonomous learning interest and depth of study.
\end{abstract}

\section{Introduction}

Currently, inquiry-based education in science education is the great concern of the world of science education. Since the 1990s, the United States introduced the "National Science Education Standards," and "2061" emphasis on scientific inquiry to learn the necessary scientific research center link, school teachers need to use different teaching strategies depending on the situation in the two science education literature to improve students' grasp of scientific knowledge and research ability[1]. Therefore, the world education sector is widely inquiry-based teaching educational experiment, and it is the gradual formation of a new type of inquiry teaching mode. To this end, in the college teaching of Marxism, the teachers are happy to research the science education development in the current international community through scientific inquiry teaching mode reference value for teaching of Marxism, as well as colleges, universities, and the Marxist science education reform and the rapid development of the provision of teaching, this is an important role in the spread of Marxism[2].

\section{Basic theories and methods of scientific inquiry teaching mode}

A. The basic theory of scientific inquiry teaching mode

Teaching model is a consensus of scientific concepts: Through long-term practice it can form educational ideal objective, target and teaching implementation plan under the guidance of certain teaching theory and teaching ideas. While the education ideal objective, target means that through the concrete teaching to achieve the desired teaching results, the specific process needs to have very clear teaching aims, objectives, and the purpose, goals must be correct and build on the beneficial for teaching theory and teaching thought and the objective existence of the teaching law. Scheme is able to achieve the teaching purpose, the target of an optimistic approach, mode of action, implementation steps in the process of teaching.

$B$. The classification of scientific inquiry teaching mode

About scientific inquiry teaching mode types, based on the basic theory the teaching mode is divided into five categories, information processing teaching mode, teaching model of personality development, personality development, teaching mode, behavior modification in teaching mode as well as learning inquiry teaching mode. Information processing teaching model is based on information processing theory, and it uses teaching as the creative process of an information 
processing. Personality development teaching mode is based on the people capitalism teaching thinking as a guidance and individualized educational theory. Personality development teaching model is based on social interaction theory methods, such as group exploration mode, as well as the social survey mode. Behavior modification teaching model is based on the theory of human behavioral psychology[3]. Learning science inquiry teaching mode is for the students to build an open-campus learning environment, and it can help them to take the initiative to acquire knowledge and to guide its use of theory and practice, integrated research capability to develop the courage to explore the spirit.

C. The structure of scientific inquiry teaching mode

Elements of scientific inquiry teaching mode are not irreplaceable, namely the basic structure of complete scientific inquiry teaching mode consists of four factors, and they are the basis of theoretical methods, the educational function of the target, practice operating procedures and environmental conditions.

D. Characteristics of scientific inquiry teaching mode

Characteristic of scientific inquiry teaching mode mainly have: operation, education programs that provided make students easily understand and grasp the connotation and have rational application; parsimony is the simple structure of teaching basic theory framework and the traditional teaching activities, concise language, schema or symbol expression meaning; pertinence, identification of different types of the education target specific methods and skills, and with target having the specific adaptation of the model; integrity is a complete set of teaching structure, grasp the overall in the teaching process; open dynamic is open teaching system, the theory and method of continuous has continuous development and innovation[4].

$E$. The function of scientific inquiry teaching mode

The main function of scientific inquiry teaching mode is : describe the formation of functional and all factors as well as the relationship between the teaching contained in the whole process, and it has a strong teaching cohesion and personality characteristics; consulting interpretation, it is through the brief text or graphic symbols to describe the process of teaching the theoretical basis, make its intuitive and easy to be understood; diagnosis prediction function, which can have carefully comprehensive diagnosis for the education and teaching process of all the activities, find the problem and explain the reasons to promote teaching reform.

\section{Construction of Marx's scientific inquiry teaching mode}

Scientific inquiry teaching theory has practice teaching, firstly establishes scientific inquiry teaching model. Along with development of the science inquiry teaching mode of the basic theory and method of teaching research and practice, at the same time, the Marx doctrine teaching also has its own unique characteristics of teaching, therefore, combined with characteristics of the Marx doctrine in the practice teaching process to establish following Marx's scientific inquiry teaching mode[5].

Teaching model in Figure 1 shows that the entire scientific inquiry teaching model is based on the following specific procedures to run。

According to Figure 2, set up Marx's inquiry teaching strategy can use natural phenomena, social problems, and the students themselves the divisive issue of problem scene creation. At the same time, from the angle of scientific research organization, guide students to carry on data collection, organizing students to plan and discuss the methods of solving questions, inducing students to explore the problem solving strategy. Third, in the teaching mode, teachers give students a expression and communication platform, make the students thinking ability and oral communication ability. Finally, knowledge migration theory and method of Marx's theory in the teaching can have migration to modern teaching.

\section{Practical research process of scientific inquiry teaching mode}

In order to verify the scientific inquiry teaching modes, it can select 100 pupils of a city college were the research object of Marx teaching, and it is divided into the experimental group of 50 and 
contrast group of 50. The selection of teaching content for: Marx's basic theory, guiding ideology and principle, while exploring the Marx doctrine thought history. Establishment of inquiry teaching objectives and conditions are shown in Table 1.
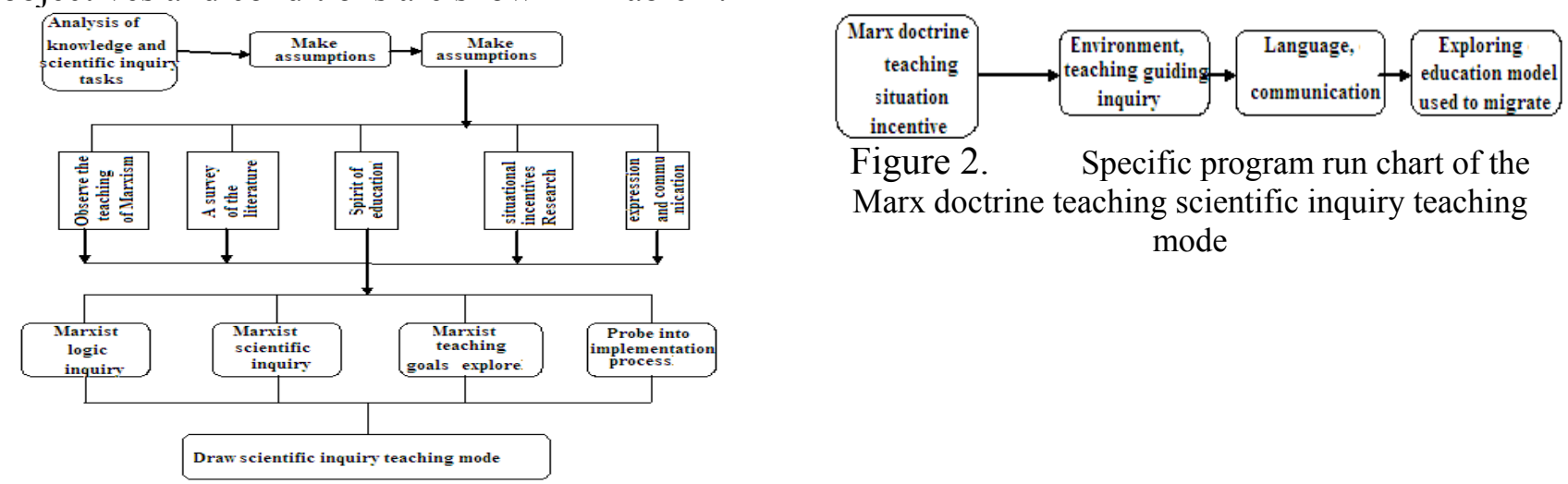

Figure 2. Specific program run chart of the Marx doctrine teaching scientific inquiry teaching mode

Figure 1. Graph of the Marxist teaching science inquiry teaching mode

\begin{tabular}{|l|l|}
\multicolumn{2}{c}{ TABLE I. } \\
\multicolumn{1}{c|}{ THE RESEARCH CONTENT } \\
\hline Understanding of Marx s scientific inquiry process & $\begin{array}{l}\text { 1. In the process of scientific inquiry to conduct a preliminary } \\
\text { understanding; } \\
\text { 2.Independent of Marx's learning, cultivating scientific interest } \\
\text { and confidence in Marx's inquiry. }\end{array}$ \\
\hline Independently explore Marx's practice experience & $\begin{array}{l}\text { 1. Students' initiative spirit of Marx thought study; } \\
\text { 2.Communicate their research experience. }\end{array}$ \\
\hline Marx's culture collection of relevant information & $\begin{array}{l}\text { 1. Use of multiple pathways means to collect information } \\
\text { related to the Marx doctrine; } \\
\text { 2. Sorting data and information, make correct judgments. }\end{array}$ \\
\hline
\end{tabular}

The paper uses mathematical statistics to analyze data, it is assumed that there is a sample digital $\mathrm{g}$, the number of $\mathrm{p}$-element vector observations in each sample is $\mathrm{n}$, then there are gn observed value

\begin{tabular}{|c|c|}
\hline Sample & Observed value \\
\hline $\begin{array}{l}1 \\
2\end{array}$ & $\begin{array}{l}\times 11 \times 12 \times 1 n \\
\times 21 \times 22 \times 2 n\end{array}$ \\
\hline- & - \\
\hline & $\begin{array}{lll}- & - & - \\
. & - & -\end{array}$ \\
\hline $\mathbf{g}$ & $x_{E} 1 x_{E} 2 x_{E} 3$ \\
\hline
\end{tabular}

Formula for each observation vector is[7]:

$$
x_{i j}=\left(\begin{array}{c}
x_{i j 1} \\
x_{i j 2} \\
\ldots \\
x_{i j p}
\end{array}\right)=\mu+\tau_{i}+e_{i j} \quad\left\{\begin{array}{l}
i=1,2, \ldots, g \\
j=1,2, \ldots, n
\end{array}\right.
$$

The decomposition of the model can be based on the formula[8]:

$$
\begin{aligned}
& x_{i j}=\bar{x}+\left(\bar{x}_{i}-\bar{x}\right)+x_{i \dot{j}}-x_{i} \\
& \text { Valuation value of treatment effect } \hat{\tau}_{i} \text { Surplus } \hat{e}_{i j}
\end{aligned}
$$

Observation value Mean value ${ }^{\mu}$ Valuation value of treatment effect ${ }^{\hat{\tau}_{i}}$ Surplus $\hat{e}_{i j}$
After a long practice teaching, then it can have statistics of Marx's scientific inquiry teaching mode. The experimental group in the Table 2 was the teaching effect after a year of Marx's scientific inquiry teaching mode after investigation, survey data was on the type of mathematical statistics and analysis. A comparison group did not participate in the experimental students' survey.

Table 2 and Figure 3 shows, students who had the inquiry teaching mode of the Marx doctrine education teaching, have more interest in the Marx principle, suggesting that, inquiry teaching mode can play the students' autonomous learning interest, result in Marx's own emotional learning, this is conducive to Marx's educational reform and development.

Table 3 and Figure 4 shows that, without the use of scientific inquiry teaching mode of Marx's education and teaching effect is very poor, only $18 \%$ of the students are able to know a little about the Marx doctrine. While the use of inquiry mode teaching method in the experiment group, $74 \%$ of 
the students in the Marx doctrine have a more profound understanding. These shows, inquiry teaching mode can lead the students to the Marx doctrine of in-depth research; truly analyze themselves and master the Marx's connotation and the respect such as guiding ideology. From the experimental group and contrast group teaching situation can be seen as the inquiry teaching mode of teaching has the remarkable difference, the inquiry teaching mode in Marx's education teaching is successful.

TABLE II. TABLES OF STUDENTS’ INTEREST IN MARXIST EDUCATION TEACHING

\begin{tabular}{|l|l|l|l|l|}
\hline & & \multicolumn{1}{|c|}{$\begin{array}{c}\text { Do } \\
\text { not } \\
\text { like }\end{array}$} & General & Like \\
\hline $\begin{array}{l}\text { Experimental } \\
\text { group (50) }\end{array}$ & $\begin{array}{l}\text { Number of } \\
\text { people }\end{array}$ & 3 & 12 & 35 \\
\cline { 2 - 5 } & Proportion & 0.06 & 0.24 & 0.7 \\
\hline $\begin{array}{l}\text { Comparison } \\
\text { group (50) }\end{array}$ & $\begin{array}{l}\text { Number of } \\
\text { people }\end{array}$ & 15 & 24 & 11 \\
\cline { 2 - 5 } & Proportion & 0.3 & 0.48 & 0.22 \\
\hline
\end{tabular}

TABLE III. TABLES OF COMPARING TO STUDENTS' UNDERSTANDING OF THE MARXISM TEACHING

\begin{tabular}{|l|l|l|l|l|}
\hline & & $\begin{array}{c}\text { Do not } \\
\text { know }\end{array}$ & General & Understand \\
\hline $\begin{array}{l}\text { Experimental } \\
\text { group (50) }\end{array}$ & $\begin{array}{l}\text { Number of } \\
\text { people }\end{array}$ & 2 & 11 & 27 \\
\cline { 2 - 5 } & Proportion & 0.04 & 0.22 & 0.74 \\
\hline $\begin{array}{l}\text { Comparison } \\
\text { group (50) }\end{array}$ & $\begin{array}{l}\text { Number of } \\
\text { people }\end{array}$ & 19 & 22 & 9 \\
\cline { 2 - 5 } & Proportion & 0.38 & 0.44 & 0.18 \\
\hline
\end{tabular}

\section{Conclusion}

Through the inquiry teaching mode to have education and teaching, this makes students have their own learning and easy mastery of knowledge. At the same time, students develop their scientific quality; exercise their own science learning ability. On the inquiry teaching mode, that teachers impart to students is not the purely mechanical theory, but to help students construct their own learning process. I t can through its own scientific research method to seek knowledge. In this inquiry teaching in the classroom, the students' thinking can get the biggest play, participation in which experience success, frustration, cooperation is conducive to students' healthy development. In addition, students in this teaching mode are not only to master Marx's connotation, development of themselves also promote the reform and development of teaching and teachers. In scientific inquiry teaching process, students can put forward creative problem, in order to inspire teachers, continuous improve and perfect the teaching content and teaching method.

\section{References}

[1] $\mathrm{Hu}$ Xinghong. About school implementation scheme of research study[J]. Shanghai research on education, 2011(1):46-48

[2] He Kekang. Constructivism - reform the traditional teaching theory basis [J].Audio-visual education .2009(5):76-77.

[3] Wang Xinchun. Density concept teaching with scientific inquiry mode[J]. Physics bulletin, 2009(2):89

[4] Liu Liping, Liu Haixia. The application of the inquiry learning in the English teaching $[\mathrm{J}]$. China Education Daily, 2011(5):103-105.

Shi Weiqin. How to guide the students to carry out inquiry learning in the English teaching[J]. China modernization of education, 2009(2):81-84 